\title{
Can Digital Health Interventions Improve Adherence to Antiretroviral (ART) for Patients Living with HIV/AIDS in Sub-Saharan Africa? Systematic Review
}

\author{
Sikota Sharper ${ }^{1}$, Chikumbe Sanhkwa Evans ${ }^{1}$, Mufalali Simasiku Mwiya ${ }^{1}$, Regina Muduli $^{1} \&$ Bevis Phiri $^{2}$ \\ ${ }^{1}$ Kwame Nkrumah University, Department of Economics and Finance, Plot 1583 Munkoyo Street, Kabwe, \\ Zambia \\ ${ }^{2}$ Clinton Health Initiative, CHAI, 175 Kudu Rd, Lusaka, Zambia \\ Correspondence: Sikota Sharper, Kwame Nkrumah University, Department of Economics and Finance, Plot 1583 \\ Munkoyo Street, Kabwe, Zambia. E-mail: sikotasharper@gmail.com
}

Received: September 20, 2020 Accepted: October 24, 2021 Online Published: November 8, 2021

doi:10.5539/gjhs.v13n12p81 URL: https://doi.org/10.5539/gjhs.v13n12p81

\begin{abstract}
Background: Human Immunodeficiency Virus (HIV) infection is one of the most devastating human pandemics in Sub-Saharan Africa (SSA) and this is the region most hit by pandemic. Adherence to Antiretroviral Therapy (ART remains challenging and varies between $27 \%$ and $80 \%$ compared to the required level of $95 \%$. Lack of adherence is of one the major causes of treatment failures. Given the increase in the use of mobile phones in Africa, text messaging is seen as a potential strategy to improve medication adherence although there is little evidence to support this argument. The aim of this review is to evaluate the efficacy of text messaging interventions to improve adherence to antiretroviral treatment.
\end{abstract}

Methods: The Effective Public Health Practice Project (APHPP) tool was used to ensure that included Randomized Controlled Trials (RCT) studies follow vigorous methodological standards including selection bias, study design, confounders, blinding, data collection methods, and withdrawal and dropout. Selected bibliographic databases MEDLINE, Web of Science, and CINAHL Plus were searched for relevant articles published in English and dated between 2005 and 2018. Six trials met the inclusion criteria as set out in the protocol. Due to the inconsistency and the likely observed heterogeneity, narrative synthesis of evidence was carried out.

Results: The results from $2 / 3$ of included studies provided evidence that text messages reminders improve adherence to antiretroviral treatment whereas $1 / 3$ produced contradictory results. Nevertheless, weekly Short Messaging Service (SMS) reminders were more effective than daily (SMS) in achieving 95\% self-reported adherence to antiretroviral treatment and in reducing the frequency of treatment interruptions. The results indicated that patients receiving text messages had their plasma HIV viral load suppressed, median CD4+ cell counts increased and were on $100 \%$ on time picking up monthly ART refills compared to the control.

Conclusion: Included studies in this review provided evidence that simple SMS reminders were important in improving and sustaining optimal ART adherences. Text messaging is seen as potential strategy to improve medication adherence. Therefore, it should be included in health systems strategies to help improve sustainable development goals. The results suggest that preventing treatment failure can be achieved by SMS reminders in a resource limited setting.

Keywords: adherence, text messaging, mobile phone, HIV, ART, SMS reminders

\section{List of Abbreviations}

AIDS: Acquired Immune Deficiency Syndrome

ART: Antiretroviral

CD: Communicable Diseases

CI: Confidence Interval

DHI: Digital Health Intervention 
EPHPP: Effective Public Health Practice Project

HIV: Human Immunodeficiency Virus

LMIC: Low and Midddle Income Countries

OR: Odds Ratio

PICOS: Population Intervention Comparator Outcome Setting

PRISMA: Preffered Reporting Item for Systematic Reviews and Meta-Analysis Statement

RCT: Randomized Controlled Trial

RR: Relative Risk

SMS: Short Messaging Service

SSA: Sub-Saharan Africa

UNAID: Joint United Programme on HIV/AIDS

\section{Introduction}

Communicable diseases (CD), including HIV/AIDS is the leading cause of death and disability in Sub- Saharan Africa (SSA) (Fox et al., 2016). HIV infection is one of the most devastating human pandemics in SSA and this is the region most hit by HIV/AIDS (Jacob et al., 2017). It's home to 19.6 million people living with HIV (UNAIDS, 2018). In 2017, 66\% of patients with HIV were receiving Antiretroviral Therapy (ART) in SSA (UNAIDS, 2018) and this number is expected to increase in the coming years with increased treatment uptake. The advent of ART has saved millions of lives and transformed HIV infection into a treatable chronic disease (Jacob et al., 2017; Van der Kop et al., 2013). Nevertheless, adherence to ART remains challenging and varies between $27 \%$ and $80 \%$ compared to the required level of $95 \%$ (Jacob et al., 2017). Lack of adherence is of one the major causes of treatment failures (Devi et al., 2015; Kiwanuka et al., 2018; Linnemayr et al., 2017; Martin \& Upvall, 2016). This has led to drug resistance, HIV disease progress, and increasing mortality (Kiwanuka et al., 2018; Linnemayr et al., 2017). Ensuring strict adherence to ART regimens remains a formidable challenge in SSA (Martin \& Upvall, 2016; Nachega et al., 2010; Van der Kop et al., 2013). Figure 1 shows the percentage of adults and children on ART in selected countries in SSA.

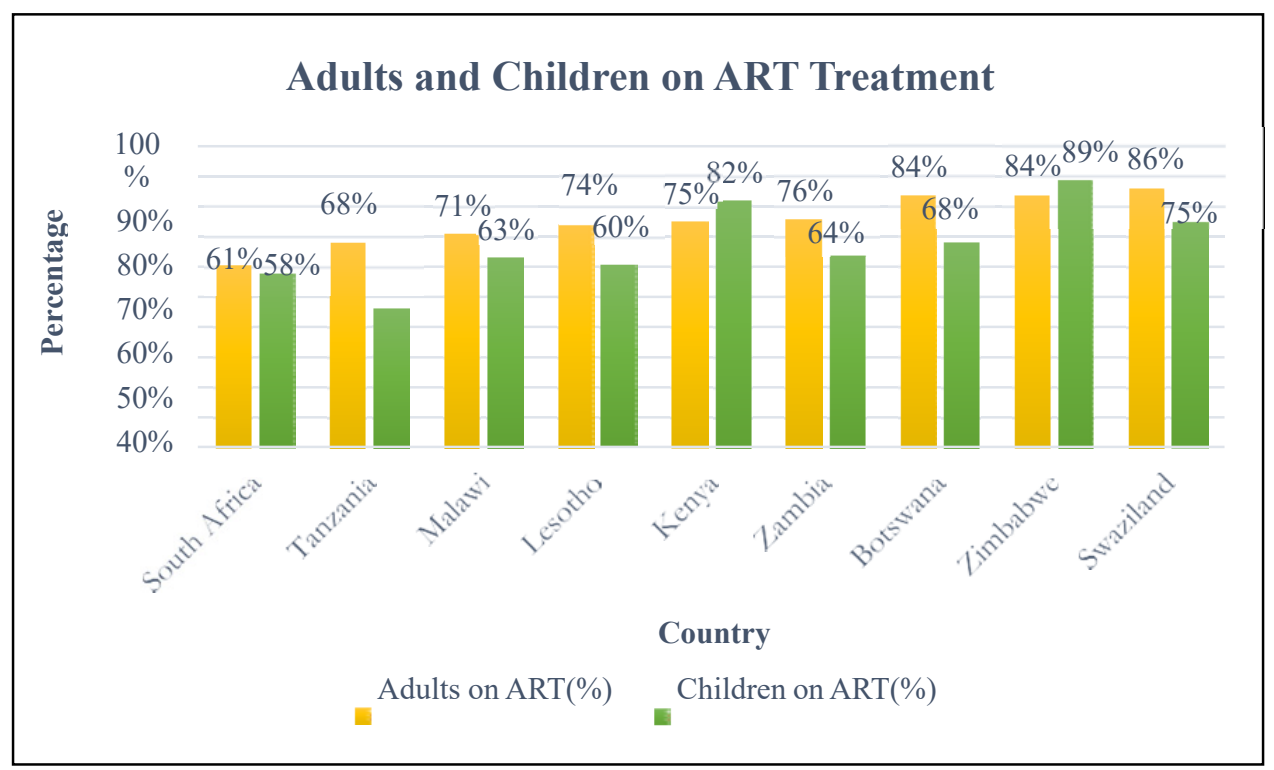

Figure 1. Adults and Children on Antiretroviral Treatment, Source: UNAID data 2017

There is no consensus about the best approach to improve ART adherence in SSA. Nevertheless, the effectiveness of medications depends on the patients' adherence (Finitsis et al., 2014). Adherence measures could be self-report, pill count, and pharmacy pickups (Finitsis et al., 2014; Horvath et al., 2012). Horvath et al. (2012) stressed that ART could help People Living with HIV (PLHIV) to live longer and sluggish progression of the virus. However, in 
the long run, their findings indicated that many PLHIV find it difficult to adhere to medications they have been prescribed. It is important to note that there many factors that affect adherence to ART including forgetting doses, being aware from home, changes in daily routines, lack of interest to take medications, alcohol use, and lack of clear information on medications (Kim et al., 2015). Research has shown that treatment adherence is one of the most important predictors of treatment effectiveness, viral suppression of HIV replication, ART drug resistance, and disease progression (Axelsson et al., 2015; Fox et al., 2016; Nachega et al., 2010). The text- messaging intervention is an emerging tool in managing people living with HIV to adhere to treatment. However, many studies diverge on the effectiveness of text messaging in improving adherence (Mbuagbaw et al., 2011).

Digital Health Intervention (DHI) has grown exponentially in the past decade opening the possibility that internet and smart phone could improve ART adherence and viral load suppression for people living with HIV/AIDS (Chow et al., 2016; Kampmeijer et al., 2016). Such modalities as telemedicine, web-based strategies, emails, mobile phones, mobile applications, and text messaging can help the overburdened health care facility and providing an often less costly alternative in the community to scale-up the uptake of ART. However, there is a lack of evidence on the benefit of DHI in the area of ART adherence. Significant challenges include the large numbers of people on ART who face economic constraints to sustained treatment access (Déglise et al., 2012; Nachega et al., 2010). On the other hand, the mobile phone network has spread rapidly throughout SSA and communications through text messages has become extremely popular. Therefore, mobile phone text-messaging has the potential to enhance patient adherence to ART regimens (Horvath et al., 2012; Kim et al., 2015; Kiwanuka et al., 2018).

Text messaging interventions have been proposed as a potential strategy to support ART adherence. This is because many resource-limited settings like SSA have well developed cellular telecommunication networks and mobile phone ownership has grown dramatically (Devi et al., 2015). Given the increase in the use of phones in SSA, text messaging is seen as a potential strategy to improve medication adherence among people living with HIV although there is little evidence to support this argument. A scooping review was carried out to identify trials that focussed on effectiveness of text messaging intervention to improve adherence to ART and found three reviews conducted in Africa (Aranda-Jan et al., 2014; Linde et al., 2019; Smith et al., 2015). However, the current review focused on reviewing the evidence on the effectiveness of text messaging to improve adherence to ART treatment in SSA. Furthermore, to explore the effectiveness of telephone interventions on adherence outcomes including self-reported adherence, viral load suppression, pharmacy refill, and CD4 cells count.

\section{Method}

The review was designed to comply with the Preferred Reporting Items for Systematic Reviews and Meta-Analysis Statement (PRISMA) including procedures of search, screening and eligibility of the articles, quality assessment, data extraction, synthesis, and analysis. The criteria for including studies followed the PICOS format: Population, Intervention, Comparator, Outcome, and Setting (PICOS) criteria. Furthermore, a clearly defined protocol was developed to ensure that the study was replicable elsewhere.

\subsection{Search Strategy}

Potential studies were identified through a range of methods, including extensive search of electronic databases. Selected bibliographic databases MEDLINE, Web of Science, CINAHL Plus with full text, Cochrane Library (Wiley) and Cochrane Central Register of Controlled Trials (CENTRAL) were searched for relevant articles published in English and dated between 2005 and 2018. Some key terms were developed in the context of review of the inclusion criteria. A summary of search terms used is given below. 
Table 1. Search Terms

\begin{tabular}{|c|c|c|c|}
\hline Population & $\begin{array}{l}\text { HIV patients } \\
\text { on ART }\end{array}$ & S1 & $\begin{array}{l}\text { ("HIV infections" OR HIV OR HIV-1* OR HIV infect*OR "human immunodeficiency } \\
\text { virus" OR ART OR "antiretroviral treatment" OR "antiretroviral therapy" OR } \\
\text { "antiretroviral drugs" OR "human immun*") AND (AIDS OR "acquired immune } \\
\text { deficiency syndrome" OR "acquired immune- deficiency syndrome" OR HIV/AIDS OR } \\
\text { "sexually transmitted diseases") }\end{array}$ \\
\hline Intervention & Mobile phone & $\mathbf{S 2}$ & $\begin{array}{l}\text { "Text message" OR message* OR SMS OR "mobile phones" OR "cellular phone", OR } \\
\text { text* }\end{array}$ \\
\hline Outcome & Adherence & $\mathbf{S} 3$ & $\begin{array}{l}\text { "Medication adherence" OR adherence OR compliance OR conform* OR keep*OR } \\
\text { observe* OR, abide* }\end{array}$ \\
\hline \multirow[t]{2}{*}{ Setting } & $\begin{array}{l}\text { Sub-Saharan } \\
\text { Africa }\end{array}$ & $\mathbf{S} 4$ & $\begin{array}{l}\text { "Sub-Saharan Africa" OR SSA OR "Sub Saharan Africa" OR Africa OR "Africa South of } \\
\text { Sahara" OR "Low and Middle Income countries" OR LMIC OR "less developed countries" } \\
\text { OR "developing countries" OR "East Africa" OR "West Africa" OR "Southern Africa" OR } \\
\text { "Central Africa" OR Benin OR Burkina Faso OR "South Africa" OR Seychelles OR } \\
\text { Namibia OR Mauritius OR Gabon OR Botswana OR Angola OR Zambia OR Nigeria OR } \\
\text { Swaziland OR Mauritania OR Sudan OR Lesotho OR Senegal OR Ghana OR Cote d'Ivoire } \\
\text { OR Congo OR Cameroon OR Zimbabwe OR Uganda OR Togo OR "South Sudan" OR } \\
\text { Somalia OR Sierra Leone OR Rwanda OR Tanzania OR Niger OR Mozambique OR Mali } \\
\text { OR Malawi OR Madagascar OR Liberia OR Kenya OR "Guinea Bissau" OR Burundi OR } \\
\text { "Central Africa Republic" OR chad OR Comoros OR Congo OR "Democratic Republic" } \\
\text { OR Eritrea OR Ethiopia OR Gambia OR } \\
\text { Guinea }\end{array}$ \\
\hline & Combining & S5 & S1 AND S2 AND S3 AND S4 \\
\hline
\end{tabular}

\subsection{Inclusion and Exclusion Criteria}

The study included participants living with HIV/AIDS residing in SSA countries. Eligibility criteria included peer reviewed RCTs, and quasi-experimental studies that reported ART adherence as shown in Table 1. Furthermore, participants were adolescents and adults, both men and women. There was no limit on the study participants in terms of ethnicity, religion, occupation, income, and morbidities. Adherence was defined as a patient's ability to follow a treatment plan, take medications at prescribed times and frequencies, follow restrictions regarding diet and executing lifestyle corresponds with agreed recommendations from health care providers (Kassaye et al., 2016). Adherence measures considered were self-report, suppression of viral load, CD4 cell counts, and pharmacy refill (Phillips et al., 2017). Studies that involved the delivery of brief automated messages through mobile phones, mobile phone applications, and text messaging were considered as the core component of the intervention. In addition, interventions that focussed only on medication reminders were included (Montag et al., 2015). However, the studies that focused on voice speaking or "beep" as the intervention were excluded. (Chow et al., 2016) pointed out that the intervention that use behaviour change strategies including education and reinforcement of content to achieve behaviour change are critical to ensure optimal adherence to ART. Treatment as usual/current standard of care was the comparator/control. The setting for this review was SSA due to the large number of HIV patients on ART, currently at $66 \%$ of adults and $59 \%$ of children are on ART (UNAIDS, 2018).

\subsection{Screening and Study Selection}

With the assistant from LMJU library, we independently key searched key terms and fitting synonyms in the selected bibliographic databases and downloaded into EndNote. Titles and abstracts were then screened against inclusion criteria to identify relevant abstracts and articles. This was followed by full- text screening of all papers meeting eligibility criteria and those not meeting eligibility were excluded. All trials meeting the inclusion criteria based on full texts screening were retained for a detailed review and analysis. Only experimental studies were included, with much emphasis on RCT. RCT were preferred to other type studies because they deal with numerical evaluation of outcomes which are appropriate for calculating effects, whereas qualitative studies are more concerned with experiences (Martin \& Upvall, 2016). 


\subsection{Quality Assessment}

The PRISMA checklist assisted in guiding the review process (Devi et al., 2015). The checklist was used to evaluate the overall reporting quality of the review. In addition to the PRISMA checklist, Effective Public Health Practice Project (EPHPP) tool was used to ensure that included RCT studies follow vigorous methodological standards. The EPHPP tool assessed both internal and external validity of included studies and has demonstrated to yield consistent results (Kyei-Nimakoh et al., 2017). The methodological assessment and quality appraisal is of great important when conducting reviews (Melese \& Demelash, 2017). The EPHPP tool was helpful in evaluating the risk of bias for each study across six component rating: Selection bias, study design, confounders, blinding, data collection methods, and withdrawal and dropout. The tool ranks methodological quality for each component then globally. Based on the quality of each component, one trial obtained an overall quality of "Strong," 3 trials scored "moderate," and 2 trials obtained overall score of "weak". A study that was rated as "strong" had no weak rating across the six components and had low risk of bias. The three studies rated "moderate" had one weak rating across the six components and was regarded as having moderate risk of bias. Other two studies were rated "weak" because they had two or more weak ratings representing high risk of bias. The quality assessment process was done by one researcher (SS) and then verified by another researcher (Supervisor). Differences were resolved through discussion between the two researchers until consensus was reached.

\subsection{Data Extraction, Synthesis and Analysis}

The information extracted included study design, participant information, interventions, comparisons, outcome, and the effect of the intervention. Furthermore, specific details on participant characteristics were captured including age, sex, sample size, time frame, blinding, study settings, and inclusion and exclusion criteria. The primary outcomes to answer our review question were $95 \%$ adherence to ART, suppression of viral load, CD4+cell counts, and pharmacy pick up.

A summary of findings was categorized according to intervention type, outcomes measured, and the efficacy of that intervention type. Results were sorted out into these groups to facilitate comparison and interpretation of findings. The summary of estimates of the effects of text-messaging intervention and corresponding $95 \% \mathrm{CI}$, relative risks (RR), odds ratios (OR) and P- value were obtained. A narrative synthesis of the evidence was carried out. We assessed the similarities and differences between studies based on the study design, population, outcome measures, settings, and statistical summary estimate. Due to the inconsistency in the summary estimates across studies and the likely observed heterogeneity, the studies were not similar and comparable, therefore, meta-analysis was not appropriate, and results were presented in a form of narrative synthesis.

\section{Results}

\subsection{Results of the Search}

The search retrieved 186 prospective studies, of which 28 were duplicates and were excluded. After the initial screening, 111 articles were excluded based on title. The remaining 37 articles were reviewed based on the content of the abstracts and 23 articles were excluded. 14 full text articles were screened for eligibility by applying the inclusion criteria relevant to study design, intervention, participants, and outcome characteristics. Most importantly, two authors independently examined articles based on titles, abstracts, and full text to identify articles that met the inclusion criteria and reported the outcome interest. The authors compared the outcomes of the screening process and found common agreement. Figure 2 illustrates the flow chat of references meeting the inclusion criteria and only 6 studies were included for review (Lester et al., 2010; Linnemayr et al., 2017; Maduka \& Tobin-West, 2013; Nsagha et al., 2016; Pop-Eleches et al., 2011; Reid et al., 2017). 


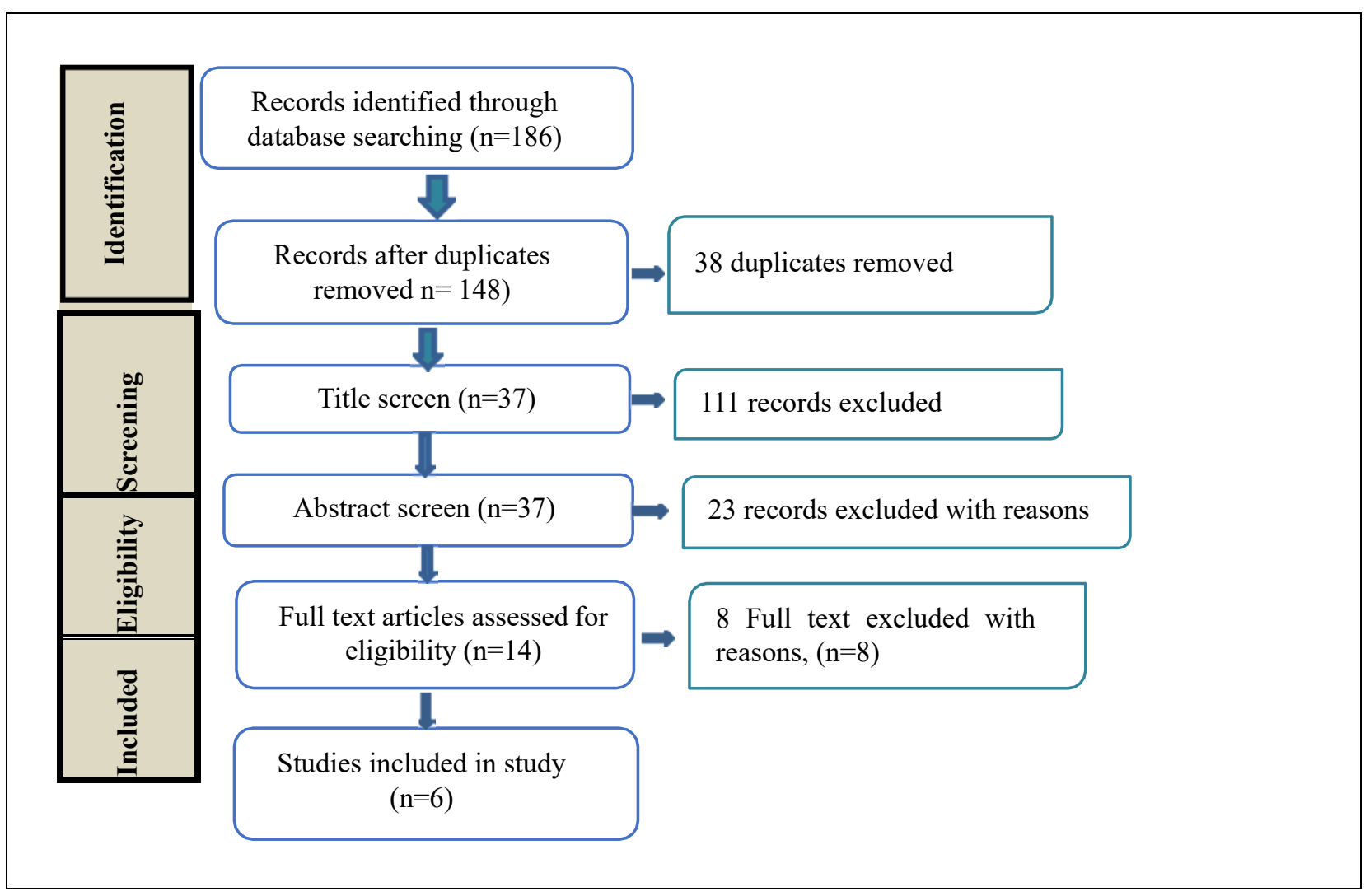

Figure 2. Study Flow Diagram

\subsection{Characteristics of Included Studies}

All selected studies were Randomized Controlled Trials (RCT) with a study population ranging from 90 to 538 participants on ART as shown in Table 2. The studies were conducted in SSA from 2005 to 2018 and in 5 different countries, two studies were from Kenya (Lester et al., 2010; Pop-Eleches et al., 2011), one study from Nigeria (Maduka \& Tobin-West, 2013), Botswana (Reid et al., 2017), Cameroon (Nsagha et al., 2016), and Uganda (Linnemayr et al., 2017) respectively. The total number of study population included was 1600, with 933 assigned to text messaging intervention and 667 to control groups. The age range was 18 to 70 for all the participants included in the studies, with majority of them aged 18 to 30 . The female participants represented $80 \%$ of the study population, this is because two studies solely recruited female population (Linnemayr et al., 2017; Pop-Eleches et al., 2011) and only four studies focussed on both males and females (Lester et al., 2010; Maduka \& Tobin-West, 2013; Nsagha et al., 2016; Reid et al., 2017). Furthermore, the timeframe of the included studies ranged from 2 months to 12 months. Additionally, all study personnel were blinded to allocation and grouping during the study period, with exception of one study (Nsagha et al., 2016). The control was standard of care for five studies including (Lester et al., 2010; Linnemayr et al., 2017; Maduka \& Tobin-West, 2013; Nsagha et al., 2016; Pop-Eleches et al., 2011; Reid et al., 2017) except (Pop-Eleches et al., 2011) in which the control was the provision of a cell phone, but this cell phone received no text messages. 
Table 2. Characteristics of studies included in the review

\begin{tabular}{|c|c|c|c|c|c|c|c|c|c|c|c|c|c|}
\hline Study ID & $\begin{array}{l}\text { Study } \\
\text { area }\end{array}$ & Study design & Blinding & & $\begin{array}{l}\text { Study } \\
\text { period }\end{array}$ & $\begin{array}{l}\text { Sample } \\
\text { size }\end{array}$ & Age & Sex & Inclusion criteria & Intervention & Comparator & Outcomes & $\begin{array}{l}\text { Quality of } \\
\text { evidence }\end{array}$ \\
\hline $\begin{array}{l}\text { Lester, } \\
\text { Ritvo et al. } \\
2010\end{array}$ & Kenya & $\begin{array}{l}\text { Multisite } \\
\text { randomised } \\
\text { clinical trial }\end{array}$ & $\begin{array}{l}\text { Investigators } \\
\text { masked } \\
\text { treatment } \\
\text { allocation }\end{array}$ & to & 48weeks & 538 & $>18$ & $\begin{array}{l}351 \mathrm{~F} \\
187 \mathrm{M}\end{array}$ & $\begin{array}{l}\text { Starting ART and able } \\
\text { to access a mobile } \\
\text { phone }\end{array}$ & $\begin{array}{l}\text { Weekly SMS } \\
\text { messages }\end{array}$ & $\begin{array}{l}\text { Standard } \\
\text { care }\end{array}$ & $\begin{array}{l}\text { self-reported } \\
\text { adherence, CD4 } \\
\text { count and viral } \\
\text { load }\end{array}$ & Moderate \\
\hline $\begin{array}{l}\text { Linnema } \\
\text { yr, Huang } \\
\text { et al. } \\
2017\end{array}$ & Uganda & $\begin{array}{l}\text { Randomized } \\
\text { controlled trial }\end{array}$ & $\begin{array}{l}\text { Investigators } \\
\text { were masked }\end{array}$ & & 48 weeks & 332 & $\begin{array}{l}15- \\
22\end{array}$ & $332 \mathrm{~F}$ & $\begin{array}{l}\text { Patients on ART and } \\
\text { have access to mobile } \\
\text { phones. }\end{array}$ & $\begin{array}{l}\text { Weekly 1-way } \\
\text { SMS or 2-way } \\
\text { SMS }\end{array}$ & $\begin{array}{l}\text { Standard of } \\
\text { care }\end{array}$ & $\begin{array}{l}\text { Adherence by } \\
\text { MEMS, Self- } \\
\text { reported adherence }\end{array}$ & Moderate \\
\hline $\begin{array}{l}\text { Nsagha et } \\
\text { al., } 2016\end{array}$ & $\begin{array}{l}\text { Camero } \\
\text { on }\end{array}$ & $\begin{array}{l}\text { Randomized } \\
\text { controlled trial } \\
\text { design }\end{array}$ & None & & 8 weeks & 90 & $\begin{array}{l}23 \\
-62\end{array}$ & $\begin{array}{l}55 \mathrm{~F} \\
35 \mathrm{M}\end{array}$ & $\begin{array}{l}\text { owned a cell phone, } \\
\text { able to read SMS, on } \\
\text { ARVs for at least one } \\
\text { month }\end{array}$ & $\begin{array}{l}\text { Weekly SMS to } \\
\text { patients }\end{array}$ & $\begin{array}{l}\text { Standard } \\
\text { care }\end{array}$ & $\begin{array}{l}\text { Adherence to } \\
\text { ARVs, } \\
\text { medication refill } \\
\text { appointments }\end{array}$ & Weak \\
\hline $\begin{array}{l}\text { Maduka } \\
\text { and Tobin- } \\
\text { West } \\
2013\end{array}$ & Nigeria & $\begin{array}{l}\text { Randomized } \\
\text { controlled trial } \\
\text { design }\end{array}$ & $\begin{array}{l}\text { research } \\
\text { assistants } \\
\text { blinded }\end{array}$ & were & 8 weeks & 104 & $20-70$ & $\begin{array}{l}45 \mathrm{M} \\
59 \mathrm{~F}\end{array}$ & $\begin{array}{l}\text { HIV positive clients } \\
\text { who had been HAART, } \\
\text { nonadherence below } \\
95 \%\end{array}$ & $\begin{array}{l}\text { Weekly SMS } \\
\text { reminders }\end{array}$ & $\begin{array}{l}\text { Standard of } \\
\text { care }\end{array}$ & $\begin{array}{l}\text { Self-reported } \\
\text { adherence and } \\
\text { CD4 counts. }\end{array}$ & Weak \\
\hline $\begin{array}{l}\text { Reid et al., } \\
2017\end{array}$ & $\begin{array}{l}\text { Botswan } \\
\text { a }\end{array}$ & $\begin{array}{l}\text { Randomized } \\
\text { control trial }\end{array}$ & $\begin{array}{l}\text { Masked } \\
\text { treatment } \\
\text { allocation }\end{array}$ & to & 24 weeks & 108 & $\begin{array}{l}18 \\
-70\end{array}$ & $\begin{array}{l}60 \mathrm{M} \\
48 \mathrm{~F}\end{array}$ & $\begin{array}{l}\text { HIV-infected adults } \\
\geq 21 \text { years old on ART } \\
\text { and receiving HIV care } \\
\text { at the } \\
\text { study clinic }\end{array}$ & $\begin{array}{l}\text { Monthly SMS } \\
\text { reminders }\end{array}$ & $\begin{array}{l}\text { Standard } \\
\text { care }\end{array}$ & $\begin{array}{l}\text { Pharmacy pickups, } \\
\text { viral load, CD } 4 \\
\text { counts }\end{array}$ & Moderate \\
\hline $\begin{array}{l}\text { Pop } \\
\text { Eleches et } \\
\text { al., } \\
2011\end{array}$ & Kenya & $\begin{array}{l}\text { Randomized } \\
\text { control trial }\end{array}$ & $\begin{array}{l}\text { Participants } \\
\text { blinded }\end{array}$ & were & 48 weeks & 428 & $>18$ & $428 \mathrm{~F}$ & $\begin{array}{l}\text { Initiated ART less than } \\
3 \text { months prior to } \\
\text { enrolment. }\end{array}$ & $\begin{array}{l}\text { short or long } \\
\text { SMS } \\
\text { daily/weekly }\end{array}$ & $\begin{array}{l}\text { Standard of } \\
\text { care }\end{array}$ & Adherence to ART & Strong \\
\hline
\end{tabular}

SMS; Short Messaging Service, CD4 cell counts; M; Males, F; Females, HIV; Human Immunodeficiency Virus, ART; Antiretroviral Therapy. 


\subsection{Quantitative Data Synthesis of ART Adherence Measures.}

\subsubsection{Self-Reported Adherence}

The ART adherence outcomes included self-reported adherence, suppression of viral load, CD4 counts, and pharmacy pickups. Only four trials reported self-reported adherence outcome (Lester et al., 2010; Linnemayr et al., 2017; Maduka \& Tobin-West, 2013; Nsagha et al., 2016; Pop-Eleches et al., 2011; Reid et al., 2017) as shown in Table 3. Two of these studies (Lester et al., 2010; Pop-Eleches et al., 2011) were conducted in Kenya and ART adherence was the primary outcome, measured as $>95 \%$ of prescribed doses in the past thirty days, evaluated at six months and twelve months. The results of RCT indicated that patients who received text message were at lower risk of reporting no adherence to ART at twelve months. However, the study conducted by Pop-Eleches and colleagues (Pop-Eleches et al., 2011), the results by intention to treat indicated that patients receiving text message were not statistically different from the control group at 12 months.

One study conducted in Nigeria (Maduka \& Tobin-West, 2013) indicated that $76.9 \%$ of patients in the text message group achieved adherence compared to $55.8 \%$ in the control $\left(X^{2}=5.21, \mathrm{p}=0.022, \mathrm{RR}=0.75(0.55-0.96)\right.$, Cohen's $w=0.224$. Self-reported adherence to ART was significant and effective. One disadvantage of self-reported adherence to ART is overestimating the adherence behavior of patients. However, it is considered reliable and retains a good specificity (Jacob et al., 2017). The self-reported questionnaire is commonly used method for measuring adherence in HIV patients. It is easy, flexible, rapid, and inexpensive despite the limitation of overestimating and recall biases that is inherent with it. Most importantly, the type and complexity of the questionnaire could significantly influence the results of the study. Furthermore, self-reported measures were not feasible with individuals with cognitive impairment.

\subsubsection{Suppression of Viral Load}

The suppression of viral load was reported in two trials (Lester et al., 2010; Reid et al., 2017). Lester and colleagues recruited 538 participants initiating ART aged 18 years and above. The results indicated that patients receiving text messages had their plasma HIV viral load suppressed ( $<400$ copies per $\mu \mathrm{L})$ at 12 months). Most importantly, the decreased viral load reduces the risks of HIV transmission (Haberer et al., 2017). A similar study conducted by Reid and colleagues (Reid et al., 2017) in Botswana who recruited 108 adult HIV patients. 54 participants in the intervention received SMS reminders and 54 in the control group did not. However, there were no significant results in the suppression of viral load for the period of the study.

\subsubsection{CD4 Cell Counts}

The study conducted in Nigeria (Maduka \& Tobin-West, 2013) recruited a total of 104 participants, of which 4 $3.3 \%$ were males and $56.7 \%$ females. Participants were randomized assigned into either intervention or control groups on 1:1 ratio. The intervention group received weekly short messages reminders for 4 months. The median CD4+ cell counts of the intervention group increased from $193 \mathrm{cells} / \mathrm{ml}$ to $575 \mathrm{cells} / \mathrm{ml}$ against $131 \mathrm{cell} / \mathrm{s} / \mathrm{ml}$ to 361 cells/ml in the control group. A study conducted by Reid and colleagues (Reid et al., 2017) in Botswana there did not show significant results in the CD4+ cell counts for the period of the study.

\subsubsection{Pharmacy Pick Ups}

Two included studies reported pharmacy pick up as primary outcome (Nsagha et al., 2016; Reid et al., 2017). For the study conducted by Reid and colleagues in Botswana, the results showed that $85 \%$ of those who received SMS reminders were $100 \%$ on time picking up monthly ART refills compared to $70 \%$ in the control. Another trial was conducted in Cameroon (Nsagha et al., 2016) and recruited 90 participants seeking treatment from HIV infection. Participants were randomly allocated into a treatment and control group each containing 45 participants. Female patients accounted for $61.1 \%$ and $38.9 \%$ were males. The age ranged from 12 to 62 years. The primary outcome was pharmacy refills and was calculated by evaluating the number times treatment and medication refill appointments were missed. The adherence to ART was $64.4 \%$ in the intervention group and $44.2 \%$ in the control group. The analysis of the pharmacy records data offers reliable methods for measuring adherence to ART. However, the method does not provide accurate data on a person's real commitment, therefore, text message reminders are effective interventions to make sure patients adhere to treatment (Haberer et al., 2017). Another study that was conducted in Uganda (Linnemayr et al., 2017) found contradictory results to the previous studies (Lester et al., 2010; Linnemayr et al., 2017; Maduka \& Tobin-West, 2013; Nsagha et al., 2016; Pop-Eleches et al., 2011; Reid et al., 2017). Despite the previous evidence that using text message reminders can promote ART adherence, this study shows that both intention-to-treat analysis and complete-case analysis produced statistically insignificant results. The study enrolled 332 participants aged 15 to 22 years. 220 were randomly assigned to the intervention group and 112 to the control. The mean adherence group in the control was $67 \%$ and $64 \%$ in 1 -way SMS group, and $61 \%$ in the 2-way SMS group. This study showed that SMS reminders are not always effective in achieving desired adherence to ART in young adults and adolescent. 
Table 3. Reported results of the included studies

\begin{tabular}{|c|c|c|c|c|c|c|c|}
\hline Study & Intervention & Outcome & Measured & $\begin{array}{l}\text { Intervention } \\
\text { (Control) }\end{array}$ & $\begin{array}{l}\text { Effect of the } \\
\text { intervention }\end{array}$ & P-value & Interpretation \\
\hline Pop Eleches et al., 2011 & $\begin{array}{l}\text { Short daily } \\
\text { SMS }\end{array}$ & $90 \%$ self-reported ART adherence & 48 Weeks & $70(139)$ & $\begin{array}{l}\text { RR } 0.99,95 \% \\
\text { CI } 0.82-1.20\end{array}$ & $\mathrm{P}>0.05$ & $\begin{array}{l}\text { There was no difference in adherence in } \\
\text { patients who received shortly weekly } \\
\text { messages compared to the control group. }\end{array}$ \\
\hline Pop Eleches et al., 2011 & $\begin{array}{l}\text { Long daily } \\
\text { SMS }\end{array}$ & $90 \%$ self-reported ART adherence & 48 Weeks & $72(139)$ & $\begin{array}{l}\text { RR } 0.98,95 \% \\
\text { CI } 0.77-1.24\end{array}$ & $\mathrm{P}>0.05$ & $\begin{array}{l}\text { Long daily messages had no effects on } \\
\text { adherence levels in the intervention } \\
\text { compared to the control group }\end{array}$ \\
\hline Pop Eleches et al., 2011 & $\begin{array}{l}\text { Short weekly } \\
\text { SMS }\end{array}$ & $90 \%$ self-reported ART adherence & 48 Weeks & 73(139) & $\begin{array}{l}\text { RR } 0.78,95 \% \\
\text { CI } 0.59-1.03\end{array}$ & $\mathrm{P}>0.05$ & $\begin{array}{l}\text { Patients who received weekly messages } \\
\text { were not at lower risk of adherence } \\
\text { compared to the control group }\end{array}$ \\
\hline Pop Eleches et al., 2011 & $\begin{array}{l}\text { Long weekly } \\
\text { SMS }\end{array}$ & $90 \%$ self-reported ART adherence & 48 Weeks & 74(139) & $\begin{array}{l}\text { RR } 0.79,95 \% \\
\text { CI } 0.60-1.04\end{array}$ & $\mathrm{P}>0.05$ & $\begin{array}{l}\text { Patients receiving weekly messages were } \\
\text { not lower risks of adherence compared to } \\
\text { the control group }\end{array}$ \\
\hline Pop Eleches et al., 2011 & $\begin{array}{l}\text { SMS of any } \\
\text { type }\end{array}$ & $90 \%$ self-reported ART adherence & 48 Weeks & 289(139) & $\begin{array}{l}\text { RR } \quad 0.79,95 \% \\
\text { CI } 0.64-0.99\end{array}$ & $\mathrm{P} \leq 0.05$ & $\begin{array}{l}\text { Patients receiving weekly text messages } \\
\text { of any length were at lower risk of } \\
\text { non-adherence compared to those } \\
\text { receiving daily messages of any length }\end{array}$ \\
\hline Lester, Ritvo et al. 2010 & Weekly SMS & Suppression of viral load & 52 Weeks & $273(265)$ & $\begin{array}{l}\text { RR } 0.83,95 \% \\
\text { CI } 0.69-0.99\end{array}$ & $\mathrm{P} \leq 0.05$ & $\begin{array}{l}\text { Patients who received text messages } \\
\text { were at a lower risk of experiencing } \\
\text { virologic failure }\end{array}$ \\
\hline Lester, Ritvo et al. 2010 & Weekly SMS & $95 \%$ self-reported ART adherence & 52 Weeks & $273(265)$ & $\begin{array}{l}\text { RR } 0.77,95 \% \\
\text { CI } 0.63-0.93\end{array}$ & $\mathrm{P} \leq 0.05$ & $\begin{array}{l}\text { Patients receiving text message were at } \\
\text { lower risk of reporting no-adherence to } \\
\text { ART at } 12 \text { months }\end{array}$ \\
\hline Linnemayr, Huang et al. 2017 & $\begin{array}{l}\text { Weekly 1-way } \\
\text { SMS }\end{array}$ & Mean adherence & 48 Weeks & $110(112)$ & $\begin{array}{lr}\text { Mean } & 0.64 \\
95 \% \text { CI } & 0.58-0.7\end{array}$ & $\mathrm{P}>0.05$ & $\begin{array}{l}\text { The mean adherence was } 64 \% \text { in } 1 \text {-way } \\
\text { SMS group and } 67 \% \text { in the control group }\end{array}$ \\
\hline Linnemayr, Huang et al. 2017 & $\begin{array}{l}\text { Weekly 2-way } \\
\text { SMS }\end{array}$ & Mean adherence & 48 Weeks & $110(112)$ & $\begin{array}{l}\text { Mean } 0.6195 \% \\
\text { CI } 0.56-0.67)\end{array}$ & $\mathrm{P}>0.05$ & $\begin{array}{l}\text { The mean adherence was } 61 \% \text { in the } \\
2 \text {-way SMS group and } 67 \% \text { in the } \\
\text { control. }\end{array}$ \\
\hline Nsagha et al., 2016 & Weekly SMS & Pharmacy refill & 8 Weeks & $45(45)$ & $\begin{array}{l}64.4 \% \quad \text { vs } \\
44.2 \% ; \\
\mathrm{P}=0.05 \%\end{array}$ & $\mathrm{P} \leq 0.05$ & $\begin{array}{l}\text { The adherence to ART was } 64.4 \% \text { in the } \\
\text { intervention group and } 44.2 \% \text { in the } \\
\text { control group }\end{array}$ \\
\hline
\end{tabular}


Table 3. Continued

\begin{tabular}{|c|c|c|c|c|c|c|c|}
\hline Study & Intervention & Outcome & Measured & $\begin{array}{l}\text { Intervention } \\
\text { (Control) }\end{array}$ & $\begin{array}{l}\text { Effect of the } \\
\text { intervention }\end{array}$ & P-value & Interpretation \\
\hline Maduka and Tobin-West 2013 & Weekly SMS & CD4 counts & 8 Weeks & $52(52)$ & $\begin{array}{l}575 \text { cells } / \mathrm{ml} \text { vs } \\
361.5 \text { cells } / \mathrm{ml}\end{array}$ & $\mathrm{P} \leq 0.05$ & \\
\hline Maduka and Tobin-West 2013 & Weekly SMS & $95 \%$ self-reported adherence & 8 Weeks & $52(52)$ & $\begin{array}{l}\text { RR } 0.7595 \% \text { CI } \\
0.55-0.96\end{array}$ & $\mathrm{P} \leq 0.05$ & $\begin{array}{l}\text { The results indicated that } 76.9 \% \text { of patients in } \\
\text { the text message group achieved adherence } \\
\text { compared to } 55.8 \% \text { in the control }\end{array}$ \\
\hline Reid et al., 2017 & $\begin{array}{l}\text { Monthly } \\
\text { SMS }\end{array}$ & Pharmacy pick up & 24 Weeks & $54(54)$ & $\begin{array}{l}\text { OR } 2.42,95 \% \text { CI } \\
0.94-6.27\end{array}$ & $\mathrm{P} \leq 0.05$ & $\begin{array}{l}\text { Patients who received SMS reminders were } \\
100 \% \text { on time picking up monthly ART refills } \\
\text { compared to } 70 \% \text { in the control }\end{array}$ \\
\hline Reid et al., 2017 & $\begin{array}{l}\text { Monthly } \\
\text { SMS }\end{array}$ & CD4 count & 24 Weeks & $54(54)$ & $\begin{array}{l}\text { Not statistically } \\
\text { significant }\end{array}$ & $\mathrm{P}>0.05$ & $\begin{array}{l}\text { There was no significant results in the CD } 4 \\
\text { cell counts for the patients who received the } \\
\text { weekly SMS and the control group. }\end{array}$ \\
\hline Reid et al., 2017 & $\begin{array}{l}\text { Monthly } \\
\text { SMS }\end{array}$ & Suppression of viral load & 24 Weeks & $54(54)$ & $\begin{array}{l}\text { Not statistically } \\
\text { significant }\end{array}$ & $\mathrm{P}>0.05$ & $\begin{array}{l}\text { There was no significant results in the viral } \\
\text { load for the patients who received the weekly } \\
\text { SMS and the control group }\end{array}$ \\
\hline
\end{tabular}

SMS; Short Messaging Service, CD4 cell counts; M; Males, F; Females, HIV; Human Immunodeficiency Virus; P-Value, OR; Odds Ratio, RR; Relative Risks, CI; Confidence Interval, ART; Antiretroviral Therapy.

\section{Discussion}

The results from (Lester et al., 2010; Linnemayr et al., 2017; Maduka \& Tobin-West, 2013; Nsagha et al., 2016; Pop-Eleches et al., 2011; Reid et al., 2017) studies provide evidence that text messages reminders have the potential to improve adherence to ART. Mobile phone intervention is convenient and cheap in delivering SMS to thousands of potential users over a wide area (Rougemont et al., 2009). This strategy could be helpful in achieving the UNAID 90-90-90 strategy and comprehensive ART adherence support. Adherence to ART with the support of text message intervention can be key in achieving the second and third 90s of the UNAID 90-90-90 campaign to end AIDS epidemic. The second and third 90 postulate that $90 \%$ of HIV patients should be on treatment and $90 \%$ of those on treatment should be viral suppressed. The results showed a clear positive relationship of texting messaging on improving adherence to ART. The effects were consistent across some trials in SSA (Lester et al., 2010; Mbuagbaw et al., 2011; Pop-Eleches et al., 2011). The maximum adherence to ART in people with HIV improves health outcomes and prevents drug resistance (Rougemont et al., 2009).

Weekly SMS reminders were more effective in achieving 95\% adherence to ART and in reducing the frequency of treatment interruptions (Lester et al., 2010). However, the study done by Pop-Eleches and colleagues found interesting results which suggested that weekly SMS improved adherence whereas daily SMS did not. The simple explanation for this could be that there were diminishing responses from participants due to frequently repeated reminders. Schaecher and colleagues argued that poor adherence to ART is associated with less effective viral suppression which is a risk for poorer health outcomes and treatment resistance. This has also a downstream effect on the treatment costs which is mainly donor aid in LMICs. 
A study conducted in Uganda (Linnemayr et al., 2017) found contradictory results to the previous studies (Lester et al., 2010; Linnemayr et al., 2017; Maduka \& Tobin-West, 2013; Nsagha et al., 2016; Pop-Eleches et al., 2011; Reid et al., 2017). Despite the previous evidence that suggested that using text message reminders can promote ART adherence. This study, however, showed that both intention-to-treat analysis and complete-case analysis produced statistically insignificant results. The mean adherence in the control was $67 \%$ and $64 \%$ in 1-way SMS group, and $61 \%$ in the 2-way SMS group.

A review done by Wald and colleagues (Wald et al., 2015) compared 1-way and 2-way texting messaging for medication adherence. In the 2-way text messaging, participants were given the opportunity to respond and in the 1 -way, they were not. They concluded that 2-way text messaging improves adherence whereas 1-way text messaging has little effect. Similarly, another study done by Mbuagbaw produced similar results. This study did not find a significant effect of SMS texts on improving adherence to ART over the 6 months period. However, one issue caught our attention, the intervention was wrongly classified as a 1-way text messaging but participants were offered the chance to respond to the text messages by either calling or texting back (Mbuagbaw et al., 2013)

The efficacy of the 2-way text messaging lies in probably offering more communications and care to patients than in the reminder strategy to medication. We believe that results should be generalizable to other settings with similar characteristics, as the clinic set-up in Uganda is typical of many African countries. This (Linnemayr et al., 2017) trial stands out contrary to other included studies (Lester et al., 2010; Linnemayr et al., 2017; Maduka \& Tobin-West, 2013; Nsagha et al., 2016; Pop-Eleches et al., 2011; Reid et al., 2017) because it targeted adolescents and young adult population. In this group, discontinuation to ART adherence is frequent. Lack of adherence to ART is worrying and is based on a number of factors including social stigma, inadequate communication and education, and depression related to HIV/AIDS.

Nsagha and associates pointed out that there are numerous factors associated with missing treatment which directly impact on adherence and include forgetfulness, unavailability of drugs, getting up late in the morning, travelling without taking drugs along, and coming home late (Nsagha et al., 2016). They further argued that married participants missed treatment more often than unmarried counterparts accounting for over $54 \%$. This could be because married people are more involved with family responsibilities that interfere with their adherence.

Participants with a lower level of education missed their treatment compared to those with higher education. These finding are supported by Kalichman and colleagues who pointed out that people with higher levels of health literacy adhere better to their medication. Also, those who missed drug refill appointments implied treatment interruption which contributed to poor ART adherence (Kalichman et al., 2008). The results obtained by Rougemont and colleagues who conducted a study in Cameroon showed that $30 \%$ of participants failed to return for drug refill. The causes of poor adherence included treatment side effects, limited access to ART, co-payment costs, and patient-physician relationship (Rougemont et al., 2009).

\subsection{Strengths and Limitations}

A self-reported adherence is easy, flexible, rapid, and inexpensive despite the limitation of overestimating and the recall biases that is inherent with it. The clients who reported poor adherence are more likely to have been telling the truth than those who claim good adherence. However, self-reported adherence was not feasible with individuals with cognitive impairments.

The quality of the studies was poor, and the low quality of the literature reviewed depended on selection bias, study design, confounders, blinding, data collection methods, and withdrawal and dropout. Due to the inconsistency in the summary estimates across studies and the likely observed heterogeneity the studies were not similar and comparable, therefore, meta-analysis was not appropriate, and results were presented in a form of narrative synthesis. Despite these limitations, text messaging is seen as potential strategy to improve medication adherence among people living with HIV.

Some included studies had small sample sizes and may have prevented findings from being valid and reduces both generalizability and statistical power. A smaller sample than ideal can produce misleading results and conclusions on the effects of the SMS reminders. However, the simple SMS reminder was important in sustaining optimal ART adherences. In addition, the review focused on peer-reviewed trials; some important information might have been missed from unpublished and grey publication.

We recommend more rigorous evaluation of 1-way and 2-way text messaging interventions to strengthen the evidence base. In addition, retention of patients on ART in the aftermath of initiation was omitted in this review; therefore, research attempting to understand retention on ART and adherence issues will be vital in future. 


\subsection{Conclusion}

The review of literature on measures of adherence to ART identified six published studies meeting the eligibility criteria. These studies showed that adherence to ART is one of the most important predictors of treatment effectiveness, viral suppression of HIV replication, ART drug resistance, and disease progression. However, there are numerous factors associated with missing treatment, which directly impacted on adherence and included forgetfulness, unavailability of drugs, getting up late in the morning, travelling without taking drugs along, and coming home late.

Mobile phone intervention is a convenient and cheap method in delivering SMS to thousands of people over a wide area. The simple SMS reminder was important in sustaining optimal ART adherences and it's seen as potential strategy to improve medication adherence among people living with HIV.

The review provided evidence weekly SMS reminders were more effective in achieving 95\% adherence to ART and in reducing the frequency of treatment interruptions. Therefore, mobile phone text messaging improves health outcomes and should be included in health systems strategies to help improve sustainable development goals. The results from four trials (Lester et al., 2010; Linnemayr et al., 2017; Maduka \& Tobin-West, 2013; Nsagha et al., 2016; Pop-Eleches et al., 2011; Reid et al., 2017) suggest that preventing treatment failure can be achieved by SMS interventions in a resource limited setting.

\section{Declarations}

- Ethical approval and consent to participate

Not Applicable

- Consent for publication Not Applicable

- Availability of data and material

All the data used is included in the appendix

- Funding

Not Applicable

- Author's Contributions

$\mathrm{LJ}$ reviewed and offered supervision. MC reviewed the content of the review.

- Author's Information

Sharper Sikota holds an MSc International Public Health from LJMU University in the UK, a Master of Art in Economics and from the University of Zambia. Prior to his postgraduate studies in the UK, Sharper worked as a Health Economist for a USAID funded project. His skills include statistical analysis using STATA, project management, economic evaluation, and monitoring and evaluation. Sharper has interests in health economics, communicable diseases, non-communicable diseases, inequalities, digital health, climate change, and research in LMICs.

\section{Acknowledgements}

I wish to acknowledge the full sponsorship I received from the Chevening to pursue MSc International Public Health at LJMU. I am thankful to all members of staff at LJMU Public health Institute, and I am particularly thankful Rose Khatri for her guidance, encouragement, and mentorship.

\section{Competing Interests Statement}

The authors declare that there are no competing or potential conflicts of interest.

\section{References}

Aranda-Jan, C. B., Mohutsiwa-Dibe, N., \& Loukanova, S. (2014). Systematic review on what works, what does not work and why of implementation of mobile health (mHealth) projects in Africa. BMC Public Health, 14, 188. https://doi.org/10.1186/1471-2458-14-188

Axelsson, J. M., Hallager, S., \& Barfod, T. S. (2015). Antiretroviral therapy adherence strategies used by patients of a large HIV clinic in Lesotho. Journal of Health, Population and Nutrition, 33(1), 10. https://doi.org/10.1186/s41043-015-0026-9

Chow, C. K., Islam, S. M. S., Farmer, A., Bobrow, K., Maddision, R., Whittaker, R., ... \& Rodgers, A. (2016). Text2PreventCVD: protocol for a systematic review and individual participant data meta-analysis of text 
message-based interventions for the prevention of cardiovascular diseases. BMJ Open, 6(10), e012723. https://doi.org/10.1136/bmjopen-2016-012723

Déglise, C., Suggs, L. S., \& Odermatt, P. (2012). SMS for disease control in developing countries: a systematic review of mobile health applications. Journal of Telemedicine and Telecare, 18(5), 273-281. https://doi.org/10.1258/jtt.2012.110810

Devi, B. R., Syed-Abdul, S., Kumar, A., Iqbal, U., Nguyen, P. A., Li, Y. C., \& Jian, W. S. (2015). mHealth: An updated systematic review with a focus on HIV/AIDS and tuberculosis long term management using mobile phones. Comput Methods Programs Biomed, 122(2), 257-265. https://doi.org/10.1016/j.cmpb.2015.08.003

Finitsis, D. J., Pellowski, J. A., \& Johnson, B. T. (2014). Text message intervention designs to promote adherence to antiretroviral therapy (ART): a meta-analysis of randomized controlled trials. PLoS One, 9(2), e88166. https://doi.org/10.1371/journal.pone.0088166

Fox, M. P., Rosen, S., Geldsetzer, P., Bärnighausen, T., Negussie, E., \& Beanland, R. (2016). Interventions to improve the rate or timing of initiation of antiretroviral therapy for HIV in sub-Saharan Africa: meta-analyses of effectiveness. Journal of the International AIDS Society, 19(1), 20888-20888. https://doi.org/10.7448/IAS.19.1.20888

Haberer, J. E., Sabin, L., Amico, K. R., Orrell, C., Galárraga, O., Tsai, A. C., ... \& Bangsberg, D. R. (2017). Improving antiretroviral therapy adherence in resource-limited settings at scale: a discussion of interventions and recommendations. Journal of the International AIDS Society, 20(1), 21371-21371. https://doi.org/10.7448/IAS.20.1.21371

Horvath, T., Azman, H., Kennedy, G. E., \& Rutherford, G. W. (2012). Mobile phone text messaging for promoting adherence to antiretroviral therapy in patients with HIV infection. Cochrane Database Syst Rev, 2012(3), Cd009756. https://doi.org/10.1002/14651858.Cd009756

Jacob, S. A., Jacob, D. G., \& Jugulete, G. (2017). Improving the Adherence to Antiretroviral Therapy, a Difficult but Essential Task for a Successful HIV Treatment-Clinical Points of View and Practical Considerations. Front Pharmacol, 8, 831. https://doi.org/10.3389/fphar.2017.00831

Kalichman, S. C., Pope, H., White, D., Cherry, C., Amaral, C. M., Swetzes, C., Flanagan, J., \& Kalichman, M. O. (2008). Association between health literacy and HIV treatment adherence: further evidence from objectively measured medication adherence. Journal of the International Association of Physicians in AIDS Care (Chicago, Ill. : 2002), 7(6), 317-323. https://doi.org/10.1177/1545109708328130

Kampmeijer, R., Pavlova, M., Tambor, M., Golinowska, S., \& Groot, W. (2016). The use of e-health and m-health tools in health promotion and primary prevention among older adults: a systematic literature review. $B M C$ Health Services Research, 16(5), 290. https://doi.org/10.1186/s12913-016-1522-3

Kassaye, S. G., Ong'ech, J., Sirengo, M., Kose, J., Matu, L., McOdida, P., ... \& Machekano, R. (2016). Cluster-Randomized Controlled Study of SMS Text Messages for Prevention of Mother-to-Child Transmission of HIV in Rural Kenya. AIDS Res Treat, 2016, 1289328. https://doi.org/10.1155/2016/1289328

Kim, J., Zhang, W., Nyonyitono, M., Lourenco, L., Nanfuka, M., Okoboi, S., .. \& Moore, D. M. (2015). Feasibility and acceptability of mobile phone short message service as a support for patients receiving antiretroviral therapy in rural Uganda: a cross-sectional study. Journal of the International AIDS Society, 18, 20311. https://doi.org/10.7448/IAS.18.1.20311

Kiwanuka, N., Mpendo, J., Asiimwe, S., Ssempiira, J., Nalutaaya, A., Nambuusi, B., ... \& Ssetaala, A. (2018). A randomized trial to assess retention rates using mobile phone reminders versus physical contact tracing in a potential HIV vaccine efficacy population of fishing communities around Lake Victoria, Uganda. BMC Infectious Diseases, 18(1), 591. https://doi.org/10.1186/s12879-018-3475-0

Kyei-Nimakoh, M., Carolan-Olah, M., \& McCann, T. V. (2017). Access barriers to obstetric care at health facilities in sub-Saharan Africa-a systematic review. Systematic Reviews, 6(1), 110. https://doi.org/10.1186/s13643-017-0503-x

Lester, R. T., Ritvo, P., Mills, E. J., Kariri, A., Karanja, S., Chung, M. H., ... \& Plummer, F. A. (2010). Effects of a mobile phone short message service on antiretroviral treatment adherence in Kenya (WelTel Kenya1): a randomised trial. Lancet, 376(9755), 1838-1845. https://doi.org/10.1016/s0140-6736(10)61997-6

Linde, D. S., Korsholm, M., Katanga, J., Rasch, V., Lundh, A., \& Andersen, M. S. (2019). One-way SMS and healthcare outcomes in Africa: Systematic review of randomised trials with meta-analysis. PLoS One, 14(6), 
e0217485. https://doi.org/10.1371/journal.pone.0217485

Linnemayr, S., Huang, H., Luoto, J., Kambugu, A., Thirumurthy, H., Haberer, J. E., ... \& Mukasa, B. (2017). Text Messaging for Improving Antiretroviral Therapy Adherence: No Effects After 1 Year in a Randomized Controlled Trial Among Adolescents and Young Adults. Am J Public Health, 107(12), 1944-1950. https://doi.org/10.2105/ajph.2017.304089

Maduka, O., \& Tobin-West, C. I. (2013). Adherence counseling and reminder text messages improve uptake of antiretroviral therapy in a tertiary hospital in Nigeria. Niger $J$ Clin Pract, 16(3), 302-308. https://doi.org/10.4103/1119-3077.113451

Martin, C. A., \& Upvall, M. J. (2016). A Mobile Phone HIV Medication Adherence Intervention: Acceptability and Feasibility Study. J Assoc Nurses AIDS Care, 27(6), 804-816. https://doi.org/10.1016/j.jana.2016.07.002

Mbuagbaw, L., Thabane, L., Ongolo-Zogo, P., Lester, R. T., Mills, E., Volmink, J., ... \& Ondoa, H. A. (2011). The Cameroon mobile phone SMS (CAMPS) trial: a protocol for a randomized controlled trial of mobile phone text messaging versus usual care for improving adherence to highly active anti-retroviral therapy. Trials, 12,5 . https://doi.org/10.1186/1745-6215-12-5

Mbuagbaw, L., van der Kop, M. L., Lester, R. T., Thirumurthy, H., Pop-Eleches, C., Ye, C., ... \& Thabane, L. (2013). Mobile phone text messages for improving adherence to antiretroviral therapy (ART): an individual patient data meta-analysis of randomised trials. BMJ Open, 3(12), e003950. https://doi.org/10.1136/bmjopen-2013-003950

Melese, A., \& Demelash, H. (2017). The prevalence of tuberculosis among prisoners in Ethiopia: a systematic review and meta-analysis of published studies. Archives of public health $=$ Archives belges de sante publique, 75, 37-37. https://doi.org/10.1186/s13690-017-0204-x

Montag, C., Błaszkiewicz, K., Sariyska, R., Lachmann, B., Andone, I., Trendafilov, B., ... \& Markowetz, A. (2015). Smartphone usage in the 21st century: who is active on WhatsApp? BMC research notes, 8, 331-331. https://doi.org/10.1186/s13104-015-1280-z

Nachega, J. B., Mills, E. J., \& Schechter, M. (2010). Antiretroviral therapy adherence and retention in care in middle-income and low-income countries: current status of knowledge and research priorities. Curr Opin HIV AIDS, 5(1), 70-77. https://doi.org/10.1097/COH.0b013e328333ad61

Nsagha, D. S., Lange, I., Fon, P. N., Nguedia Assob, J. C., \& Tanue, E. A. (2016). A Randomized Controlled Trial on the Usefulness of Mobile Text Phone Messages to Improve the Quality of Care of HIV and AIDS Patients in Cameroon. The open AIDS journal, 10, 93-103. https://doi.org/10.2174/1874613601610010093

Phillips, T., Brittain, K., Mellins, C. A., Zerbe, A., Remien, R. H., Abrams, E. J., ... \& Wilson, I. B. (2017). A Self-Reported Adherence Measure to Screen for Elevated HIV Viral Load in Pregnant and Postpartum Women on Antiretroviral Therapy. AIDS and behavior, 21(2), 450-461. https://doi.org/10.1007/s10461-016-1448-0

Pop-Eleches, C., Thirumurthy, H., Habyarimana, J. P., Zivin, J. G., Goldstein, M. P., ... \& Bangsberg, D. R. (2011). Mobile phone technologies improve adherence to antiretroviral treatment in a resource-limited setting: a randomized controlled trial of text message reminders. AIDS (London, England), 25(6), 825-834. https://doi.org/10.1097/QAD.0b013e32834380c1

Reid, M. J. A., Steenhoff, A. P., Thompson, J., Gabaitiri, L., Cary, M. S., Steele, K., ... \& Linkin, D. R. (2017). Evaluation of the effect of cellular SMS reminders on consistency of antiretroviral therapy pharmacy pickups in HIV-infected adults in Botswana: a randomized controlled trial. Health psychology and behavioral medicine, 5(1), 101-109. https://doi.org/10.1080/21642850.2016.1271333

Rougemont, M., Stoll, B. E., Elia, N., \& Ngang, P. (2009). Antiretroviral treatment adherence and its determinants in Sub-Saharan Africa: a prospective study at Yaounde Central Hospital, Cameroon. AIDS Res Ther, 6, 21. https://doi.org/10.1186/1742-6405-6-21

Smith, C., Gold, J., Ngo, T. D., Sumpter, C., \& Free, C. (2015). Mobile phone-based interventions for improving contraception use. The Cochrane database of systematic reviews(6), CD011159. Retrieved 2015/06//, from https://doi.org/10.1002/14651858.CD011159.pub2

UNAIDS. (2018). Global HIV \& AIDS statistics - Fact sheet. https://www.unaids.org/en/resources/fact-sheet

Van der Kop, M. L., Ojakaa, D. I., Patel, A., Thabane, L., Kinagwi, K., Ekström, A. M., ... \& Lester, R. T. (2013). The effect of weekly short message service communication on patient retention in care in the first year after 
HIV diagnosis: study protocol for a randomised controlled trial (WelTel Retain). BMJ Open, 3(6), e003155. https://doi.org/10.1136/bmjopen-2013-003155

Wald, D. S., Butt, S., \& Bestwick, J. P. (2015). One-way versus two-way text messaging on improving medication adherence: meta-analysis of randomized trials. Am J Med, 128(10), 1139.e1131-1135. https://doi.org/10.1016/j.amjmed.2015.05.035

\section{Copyrights}

Copyright for this article is retained by the author(s), with first publication rights granted to the journal.

This is an open-access article distributed under the terms and conditions of the Creative Commons Attribution license (http://creativecommons.org/licenses/by/4.0/). 